\title{
The differential role of androgens in early human sex development
}

Olaf Hiort ${ }^{1,2}$

\begin{abstract}
Sexual development in humans is only partly understood at the molecular level. It is dependent on genetic control primarily induced by the sex chromosomal differences between males and females. This leads to the development of the gonads, whereby afterwards the differentiation of the apparent phenotype is controlled by hormone action. Sex steroids may exert permanent and temporary effects. Their organizational features of inducing permanent changes in phenotype occur through genetic control of downstream genes. In this, androgens are the key elements for the differentiation of male internal and external genitalia as well as other sexual organs and general body composition, acting through a single androgen receptor. The androgen receptor is a nuclear transcription factor modulating DNA transcription of respective target genes and thereby driving development and growth in a stringent manner. The specificity of androgen action seems to be a strictly time-controlled process with the androgen receptor acting in concert with different metabolites and an array of cofactors modulating the cellular response and thereby permanently altering the phenotype of any given individual. For every cell programmed by androgens, a specific 'androgen response index' must be proposed.
\end{abstract}

Keywords: Androgen insensitivity, Androgen receptor, Androgens, Disorders of sex development, Genetics, Sex development

\section{Introduction}

Human sex development can be divided into three major steps. First, the determination of the chromosomal set with the presence or absence of a specific gene on the $Y$ chromosome termed $S R Y$, as well as the sex differences induced from the inequality of the sex chromosomes and their corresponding genes $[1,2]$. Second, the development of the gonad and its differentiation into either testis or ovary $[3,4]$. Third, the control of the phenotype of the individual by the secretion and action of specific hormones, which in turn lead to additional genetic programming. These steps have to occur in a stringent and time-dependent manner to allow any individual to develop into a male or a female. The sexual dimorphism is then a major determinant for further development of the individual and its capacity for reproduction, but also for sex-related differences in health and disease. Examples for this are differences in the occurrence of defined

Correspondence: olaf.hiort@uksh.de

${ }^{1}$ Division of Experimental Paediatric Endocrinology and Diabetes, University of Lübeck, Lübeck, Germany

${ }^{2}$ Department of Paediatric and Adolescent Medicine, University of Lübeck, Ratzeburger Allee 160, 23560, Lübeck, Germany disorders, but also alterations in pharmacologic treatment responses. This has been increasingly recognized, but the role of sex-related endocrinology has been only partly understood in its developmental aspects to date. This review will describe the differential effects of androgens in human sex development, focusing on recent knowledge obtained from human natural models of distinct differences of sex development.

\section{Developmental aspects of sexual differentiation Prenatal}

Composition of the sexual phenotype is apparently dependent on primary genetic events that stem from the differences in genes on the $\mathrm{X}$ and $\mathrm{Y}$ chromosome as well as their expression between males and females (2). However, the main aspects of gender development arise from the endocrine induced differentiation of sexual organs including the brain. Specific sex hormones present early in development affect sexual differentiation in a permanent and organizational manner.

The major hormones for differential male and female sex development are mainly secreted from the testes [3].

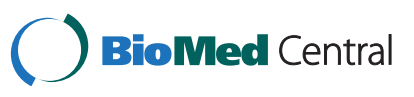

(c) 2013 Hiort; licensee BioMed Central Ltd. This is an Open Access article distributed under the terms of the Creative Commons Attribution License (http://creativecommons.org/licenses/by/2.0), which permits unrestricted use, distribution, and reproduction in any medium, provided the original work is properly cited. 
The testes form from an undifferentiated gonad around the fifth week of gestation. The Sertoli cells secrete antiMullerian hormone, a peptide responsible for the regression of the Mullerian ducts, thus inhibiting the formation of uterus and fallopian tubes in the male. From around the sixth week of gestation, the Leydig cells synthesize and secrete testosterone from cholesterol via sequential actions of specific enzymes. Testosterone reaches its target cells in a paracrine, but also in an endocrine fashion through the blood. Within the target cells, testosterone is metabolized, and the $5 \alpha$-reduced compound dihydrotestosterone (DHT) is required for androgen-induced differentiation of the external genitalia. While testosterone stabilizes the Wolffian ducts to develop into epididymis, vas deferens, and seminal vesicle, DHT induces the formation of the prostate as well as the differentiation of urogenital swellings, the genital tubercle, and the urethral folds into penis and scrotum [5].

In mammals, androgens act via a single androgen receptor (AR) in a very specific manner. Both sexes express the AR, but the usual lack of appropriate levels of androgens in the female results in the development of the genital tubercle into a clitoris, and the urogenital swellings to become the labia majora [6]. In rodents, the androgenization of the genitalia occurs in a 'masculinization programming window' between embryonic days E15.5 and E17.5 [6,7]. If male mice are treated with flutamide, a potent antiandrogen, during this time interval, the morphology of the external genitalia will be similar to female mice. In contrast, female mice will develop male morphology if they are treated with testosterone propionate during this critical period [6].

In humans, the mechanisms explaining the effects of androgens in genital development are well illustrated by naturally occurring disorders of sex development (DSD) [8]. A very interesting model to study the lack of androgenic affects is complete androgen insensitivity syndrome (CAIS). In 46,XY individuals, CAIS is caused by deleterious mutations in the AR [9]. Individuals with CAIS have normally developed testes secreting high amounts of testosterone [10]. Their external phenotype at birth is apparently completely female with a clitoris, labia majora and female separation of vagina and urethra [11]. An 'opposite' naturally occurring model is seen in individuals with 46,XX karyotype and normally developed ovaries that have high amounts of androgens during embryogenesis, for example, in congenital adrenal hyperplasia $(\mathrm{CAH})$ and adrenal androgen excess where testosterone levels can reach the usual reference intervals observed in males [12-15]. In such cases, the external genitalia may be in some cases completely masculinized with formation of a male size phallus with the urethral opening at the tip of the glans, and the urogenital swellings differentiated into a scrotum. We therefore propose a highly androgen-dependent differentiation process leading to either male (in the case of androgenization) or female genitalia (lack of androgenization), which relies on action strictly dependent on time, dose, and compound (Figure 1).

\section{Postnatal}

Postnatally, both organizational (permanent) as well as activational (temporary) effects of sex steroids are seen on sexual organ function including brain structure and behavior [16].

It seems clear that androgen action plays a major role in body composition even in the neonate, as birth weight highly correlates with androgenization status rather than chromosomal sex [17]. The effects of embryonal androgenization on specific parts of the body are not so obvious and incompletely understood. In particular, the study of biological effects on gender identity is challenging for lack of experimental designs and ethical issues.

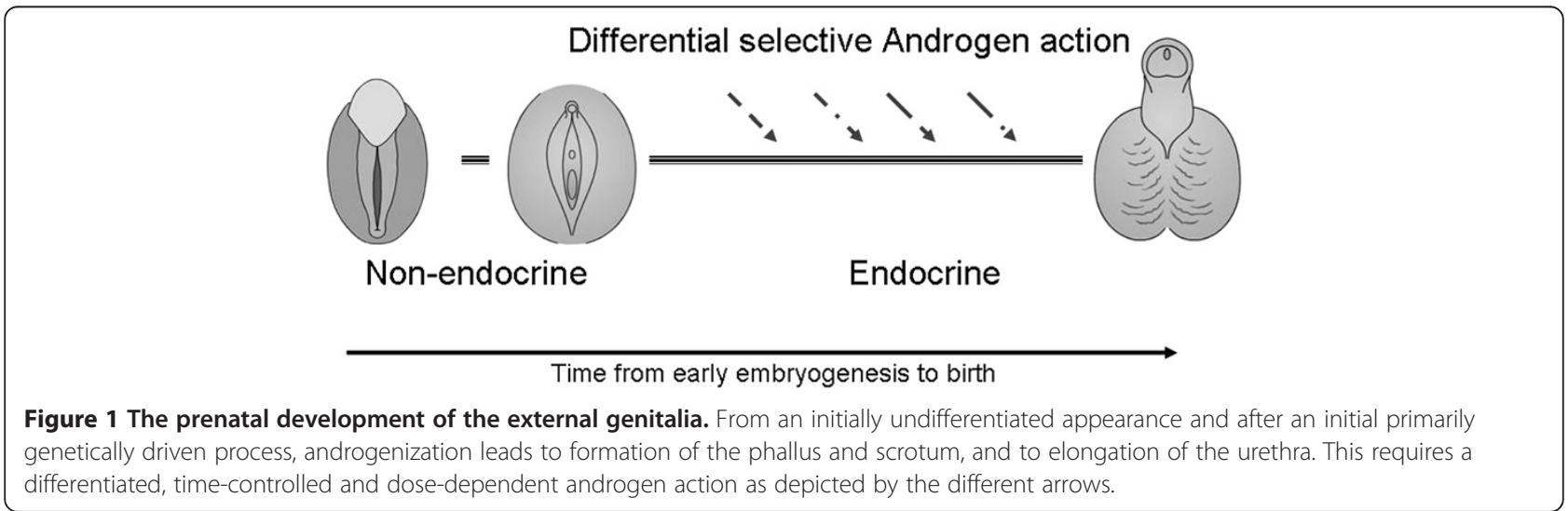


Again, mainly the naturally occurring models (CAIS and $\mathrm{CAH}$ ) have been studied [16].

It has been well described that most individuals with CAIS have a female gender identity. In contrast, 46,XX individuals with $\mathrm{CAH}$ demonstrate behavioral traits associated with maleness, but their overall gender identity is often female. In a study by Jurgensen et al. [18], children with DSD were compared to controls with regard to their gender role behavior. Child play activities were attributed either as female and male and the choices of the children documented and ranked. While 46,XY female children without any androgenization during embryogenesis, namely complete loss of gonadal function or CAIS, were choosing the same activities and interests as $46, \mathrm{XX}$ normal girls, partial androgenization lead to more male behavioral traits. This seemed to be independent from the actual status of androgens in these individuals, so that these experiments point towards a programming of behavior at least partially due to androgenization during embryogenesis [18].

Puberty is a time of very differentiated development between the two sexes. The role of estrogens becomes evident. Estrogens induce female, androgens male body composition. In CAIS, at the time of puberty a feminization is seen, despite the fact that these individuals have very high androgen levels and their estrogen levels are only in the upper male reference range [10]. This pubertal feminization in CAIS may be the result of two effects, namely the lack of androgen action in conjunction with an intracellular aromatization of testosterone to estrogens facilitating an uninhibited effect through the estrogen receptor pathway [19]. If high levels of androgens prevail in 46,XX probands with $\mathrm{CAH}$, androgenization might lead to elongation of the clitoris, muscle growth occurs and also deepening of the voice. Thus, the effects of androgens are again seen regardless of genetic sex. Furthermore, the sex hormones have quite different effects at the time of puberty compared to their role during embryogenesis, as testosterone itself is a major driver of male body composition with respect to muscle build up and growth of the phallus, but differentiating effects on the genitals are lost [9]. This obvious finding is demonstrated by the human model with naturally occurring mutations in the $5 \alpha$ reductase 2 and therefore diminished DHT synthesis. 46, $\mathrm{XY}$ children bearing defects of DHT synthesis may have female appearing external genitalia at birth, but masculinize due to unhampered testosterone synthesis at the time of puberty [20]. This may actually lead to a change of sex assignment and gender from female to male in these individuals. It has to be assumed that the gender identity in individuals with $5 \alpha$-reductase 2 deficiency may be variable and despite female appearance of the genitalia at birth, a male gender identity may be present. This would constitute an obvious mismatch between androgenization status of the external genitalia at birth and the possible androgen effects on gender identity. This point is crucial in the current debate on the genetic and endocrine differences of 'sex of brain' with regard to anatomy, behavior, and identity [21].

The biological explanation, why androgens exert such time-dependent and differentiated effects on different cells and tissues in the body through a single AR is still not well understood. Postnatally, the evolutionary biological rationale would be to obtain growth and strength to be fit for reproduction [22]. This includes the effects of androgens on muscle strength, optimization of oxygen saturation due to hemoglobin synthesis, fertility, but also requirements for sexual attraction [23].

\section{Differential androgen action}

It seems clear that overall androgen levels play a major role, but also different androgens may facilitate different effects. Deslypere et al. [24] described different effects of testosterone and DHT on the transcription of an artificial target gene in a cell-based assay. In the study by Holterhus et al. [25], a similar system was utilized to elucidate the differential effects of androgens and anabolic steroids through the AR. They could demonstrate that different hormones such as testosterone, DHT, as well as weak androgens like dehydroepiandrosterone and oxandrolone, and anabolics such as stanozolol and nandrolone, differ in their transduction of an AR-dependent target gene, but that the results also depended on the promoter system chosen in this artificial setting. From these studies it can be concluded that within the cell, different androgens influence expression of different target genes specifically $[24,25]$.

Most likely, androgen-responsive cells can metabolize steroid hormones in specific and time-dependent ways. It was demonstrated that, for example, DHT synthesis early in life is dependent on expression of $5 \alpha$-reductase type 2 in genital skin cells [26]. This expression pattern may be altered in cells from individuals with androgen insensitivity [27]. Later in life, $5 \alpha$-reductase type 2 expression dwindles and its isoenzyme $5 \alpha$-reductase type 1 is abundantly expressed [28] (Table 1). The effects on the cellular androgen milieu are so far not elucidated, but it can be perceived that the composition of androgenic metabolites can be quite variable, depending on the expression pattern of steroidogenic enzymes within the cell. In this regard it is of interest that different cell types have different expression patterns of steroidogenic enzymes that are also age dependent $[29,30]$. Furthermore, additional alternative pathways for androgen synthesis may aggravate androgenic effects due to selective expression patterns of isoenzymes or alternate enzymes. One example of this is the 'backdoor pathway' of DHT 
Table 1 Specific disorders of androgen biosynthesis and androgen action and the respective phenotypes

\begin{tabular}{|c|c|c|c|c|c|c|}
\hline Name & Disrupted pathway & OMIM & Gene & Phenotype at birth & $\begin{array}{l}\text { Phenotype at } \\
\text { puberty }\end{array}$ & Alternate pathway \\
\hline $\begin{array}{l}\text { 5a-Reductase } \\
\text { deficiency }\end{array}$ & $\begin{array}{l}\text { Dihydrotestosterone } \\
\text { synthesis }\end{array}$ & 607306 & SRD5A2 & $\begin{array}{l}\text { Pseudovaginal perineoscrotal } \\
\text { hypospadias, variable virilization }\end{array}$ & Excessive virilization & 5a-Reductase type 1 \\
\hline $\begin{array}{l}\text { 17ß-Hydroxysteroid } \\
\text { dehydrogenase } \\
\text { deficiency }\end{array}$ & $\begin{array}{l}\text { Testosterone } \\
\text { synthesis }\end{array}$ & 605573 & HSD17B3 & $\begin{array}{l}\text { Mostly almost female appearing } \\
\text { external genitalia }\end{array}$ & $\begin{array}{l}\text { Virilization, } \\
\text { sometimes slight } \\
\text { breast development }\end{array}$ & $\begin{array}{l}\text { 17ß-Hydroxysteroid } \\
\text { dehydrogenase type } 5\end{array}$ \\
\hline $\begin{array}{l}\text { Androgen } \\
\text { insensitivity }\end{array}$ & Androgen action & 313700 & $A R$ & $\begin{array}{l}\text { In complete androgen insensitivity } \\
\text { syndrome, completely female } \\
\text { external genitalia }\end{array}$ & Feminization & $\begin{array}{l}\text { Intracellular } \\
\text { aromatization to } \\
\text { estrogens }\end{array}$ \\
\hline
\end{tabular}

synthesis, which circumvents the regular pathway through testosterone, utilizing instead $3 \alpha$ hydroxysteroid dehydrogenase 3 with synthesis from androstanediol $[14,15]$. Most likely this 'backdoor' pathway is one explanation for the virilization of 46,XX girls with $\mathrm{CAH}$ through excessive DHT formation in the external genitalia and it might play an important role in intrauterine sex development.

Another example is the differential virilization of 46, $\mathrm{XY}$ probands lacking testosterone synthesis due to defects of $17 \beta$-hydroxysteroid dehydrogenase 3 . These individuals often have a female appearance at birth, but at the time of puberty they depict measurable amounts of testosterone and demonstrate a high degree of masculinization with only slight feminization. Most likely, the pubertal testosterone synthesis from excessive amounts of androstenedione is due to postnatal expression of the isoenzyme $17 \beta$-hydroxysteroid dehydrogenase 5 , which corresponds to $3 \alpha$ hydroxysteroid dehydrogenase 2 , in the Leydig cells of the testes [31] (Table 1).
The androgen-AR complex is dependent on a variety of proteins involved in its shuttling towards the nucleus, the unraveling and binding of the target DNA and also in the transduction of the complex to activate or repress target DNA transcription [32,33]. These mechanisms are seemingly shared with other steroid hormone receptors, as these receptors share the capability to bind to the same hormone responsive elements on the target DNA sequences. So there are common features of transcriptional control of steroid hormone receptors, but also specific androgen responsive elements that are only bound by the AR [33]. After binding of the ligand, the AR undergoes conformational changes and translocates to the nucleus, where it homodimerizes in a liganddependent manner. This is mediated by specific sequences within the AR itself. The binding of coregulators to regulate receptor-mediated transcription control of target genes is a complex process. These coregulators, acting as coactivators and corepressors, coordinate the intercompartmental metabolic processes

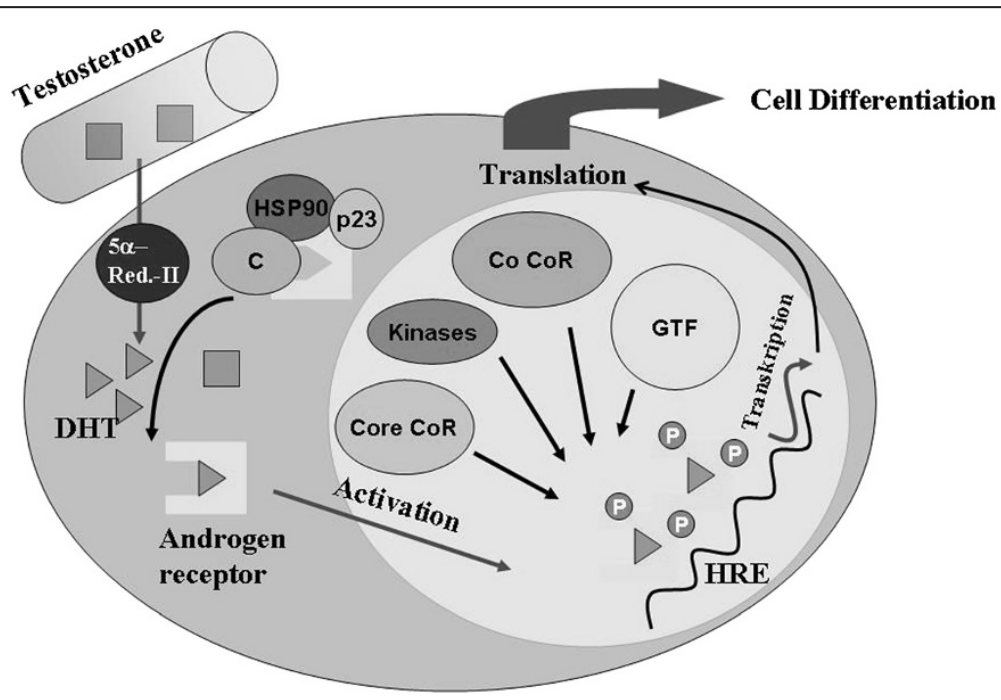

Figure 2 The androgen specific cell differentiation is dependent on testosterone uptake, its intracellular metabolism and the specificity of the androgen-androgen receptor (AR) complex in concert with coregulators in transcriptional control. CoR, coregulators; GTF, general transcription factors; HRE, hormone response elements; HSP, heat shock proteins; P, phosphorylation sites. 


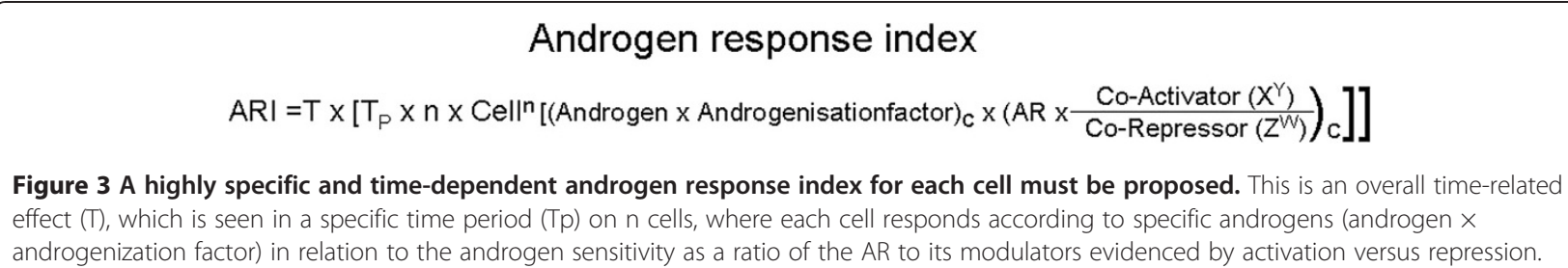

Figure 3 A highly specific and time-dependent androgen response index for each cell must be proposed. This is an overall time-related effect (T), which is seen in a specific time period (Tp) on $n$ cells, where each cell responds according to specific androgens (androgen $\times$ androgenization factor) in relation to the androgen sensitivity as a ratio of the AR to its modulators evidenced by activation versus repression.

[34]. Through the recruitment of factors such as forkhead box protein A1 (FOXA1), belonging to the forkhead box transcription factors, the AR locates its genomic target site. Other factors such as steroid receptor coactivator-3 (SRC-3) induce the assembly of the active coregulator-receptor complex [34]. For some nuclear receptors, more than 300 distinct coregulators are assumed modifying the receptor-mediated response. If the coregulators act in concert, up to $2.5 \times 10^{13}$ potential distinct coregulator-receptor complexes might be possible according to Lonard and O'Malley [35]. The differential expression pattern of coregulators will be highly cell specific and thereby lead to a cell-specific modification pattern of androgen action [36] (Figure 2).

\section{The 'formula' for cell-specific androgen programming}

If transcriptional control of androgen-dependent target cell responses is so distinct and well coordinated, the genes that compose the overall androgenization of any human should also demonstrate cell specificity. Again the human model of androgen insensitivity has served in elucidating some of these androgen-regulated genes. Interestingly, there are apparently three major points to be discussed, as follows. First, fetal sex development leads to an androgen-controlled fixed program of gene expression in the target cells. This 'basal program' is expressed throughout life and corresponds to the overall sex phenotype of a given person. Second, different cells and tissues display their individual 'androgen program, thereby depicting a topography of androgen-dependent gene expression. Third, an acute response pattern to androgens is seen with some genes in some cells.

Thus, in any individual, the responsiveness to androgens will therefore be most likely be a product of all of these factors, as proposed in an 'androgen response index' seen in Figure 3.

This proposal has its foundation in the following experiments again in cells derived from 46,XY controls and cells derived from 46,XY females mostly with CAIS: Genital skin fibroblasts, which play a role in the differentiation of the external genitalia and facilitate androgenization, are almost 'androgen insensitive' postnatally [37]. Instead they display a distinct and comprehensive expression pattern of androgen-regulated genes even in patient-derived cells that have long been androgen depleted. This fixed 'androgen-programmed' expression pattern of genes is also different depending on the localization from which the tissue was derived [38]. Overall, more than 600 genes were differentially expressed between reference cells derived from 46,XY males and proband cells from 46,XY CAIS females. In addition to the underlying fixed androgenprogrammed profile, some genes might be still be androgen responsive in the cells. One example is apolipoprotein D, which was significantly upregulated by DHT in scrotal fibroblasts in the reference cells and showed no response in the CAIS cells [39]. That in humans a cell-specific and tissue-specific prenatal fixed androgen programming may prevail was demonstrated by studying blood mononuclear cells also from CAIS individuals and from male controls. Again, a distinct set of transcripts was correlated with the external genital appearance being male or female in $46, \mathrm{XY}$ individuals, however, the transcription profile differed extensively from that derived from genital skin fibroblasts [40]. It has been hypothesized that epigenetic control through the AR may contribute to sex hormone actions. This has been evidenced by differences in HOXA5 methylation in cells from 46,XY females with CAIS and controls [41]. If the cellular effects of sex dimorphism are due to altered epigenomic programming within the target cells has to be investigated.

\section{Conclusions}

Sex and gender development in humans are tightly controlled by genetic factors inducing organ, especially gonadal development and androgen-dependent programming in a tissue-specific spatial and time-related fashion. Modulation is facilitated through endocrine, paracrine, and autocrine steroid synthesis, as well as through the recruitment of many other regulators involved in the specificity of androgen action through modification of the hormone-receptor complex. This may be calculated as an 'androgen sensitivity index'. Therapeutically, this may have several implications: Prenatal effects of androgens or the lack of androgenization cannot be reversed afterwards. This is obvious seen in genital structures, but hypothetically also is implied for other tissues, namely also brain development. Furthermore, any replacement of androgens should take into account their differential effects in androgen action and therefore supplementation of several compounds may be useful to elicit specific effects. Third, the timing of treatment with androgens is of importance for their specific impact and side effects. 


\section{Abbreviations}

AR: Androgen receptor; ARI: Androgen response index; CAH: Congenital adrenal hyperplasia; CAIS: Complete androgen insensitivity syndrome; DHT: Dihydrotestosterone.

\section{Competing interests}

The author declares that there is no competing interests.

\section{Acknowledgements}

The author received funding from the European Commission for the Project EuroDSD (no. 201444).

Received: 22 February 2013 Accepted: 29 May 2013

Published: 24 June 2013

\section{References}

1. Sekido R, Lovell-Badge R: Sex determination involves synergistic action of SRY and SF1 on a specific Sox9 enhancer. Nature 2008, 453:930-934.

2. Arnold AP: The end of gonad-centric sex determination in mammals. Trends Genet 2012, 28:55-61.

3. DeFalco T, Capel B: Gonad morphogenesis in vertebrates: divergent means to a convergent end. Annu Rev Cell Dev Biol 2009, 25:457-482.

4. Bashamboo A, McElreavey K: Gene mutations associated with anomalies of human gonad formation. Sex Dev 2013, 7:126-146.

5. Yamada G, Suzuki K, Haraguchi R, Miyagawa S, Satoh Y, Kamimura M, Nakagata N, Kataoka H, Kuroiwa A, Chen Y: Molecular genetic cascades for external genitalia formation: an emerging organogenesis program. Dev Dyn 2006, 235:1738-1735.

6. Miyagawa S, Satoh Y, Haraguchi R, Suzuki K, Iguchi T, Taketo MM, Nakagata N, Matsumoto T, Takeyama K, Kato S, Yamada G: Genetic interactions of the androgen and Wnt/beta-catenin pathways for the masculinization of external genitalia. Mol Endocrinol 2009, 23:871-880.

7. Welsh M, Saunders PT, Fisken M, Scott HM, Hutchison GR, Smith LB, Sharpe RM: Identification in rats of a programming window for reproductive tract masculinization, disruption of which leads to hypospadias and cryptorchidism. J Clin Invest 2008, 118:1479-1490.

8. Hiort O: Clinical and molecular aspects of androgen insensitivity. Endocr Dev 2013, 24:33-40.

9. Werner R, Grötsch H, Hiort O: 46, XY disorders of sex development-the undermasculinised male with disorders of androgen action. Best Pract Res Clin Endocrinol Metab 2010, 24:263-277.

10. Papadimitriou DT, Linglart A, Morel Y, Chaussain JL: Puberty in subjects with complete androgen insensitivity syndrome. Horm Res 2006, 65:126-131.

11. Bouvattier C, Carel JC, Lecointre C, David A, Sultan C, Bertrand AM, Morel Y, Chaussain JL: Postnatal changes of T, LH, and FSH in 46, XY infants with mutations in the AR gene. J Clin Endocrinol Metab 2002, 87:29-32.

12. Kamrath C, Hartmann MF, Wudy SA: Androgen synthesis in patients with congenital adrenal hyperplasia due to 21 -hydroxylase deficiency. Horm Metab Res 2013, 45:86-91.

13. Flück CE, Meyer-Böni M, Pandey AV, Kempná P, Miller WL, Schoenle EJ Biason-Lauber A: Why boys will be boys: two pathways of fetal testicular androgen biosynthesis are needed for male sexual differentiation Erratum in. Am J Hum Genet 2011, 89:347.

14. Kamrath C, Hochberg Z, Hartmann MF, Remer T, Wudy SA: Increased activation of the alternative "backdoor" pathway in patients with 21-hydroxylase deficiency: evidence from urinary steroid hormone analysis. J Clin Endocrinol Metab 2012, 97:E367-E375.

15. Biason-Lauber A, Miller WL, Pandey AV, Flück CE: Of marsupials and men: "backdoor" dihydrotestosterone synthesis in male sexual differentiation. Mol Cell Endocrinol 2013, 371:124-132.

16. Berenbaum SA, Beltz AM: Sexual differentiation of human behavior: effects of prenatal and pubertal organizational hormones. Front Neuroendocrinol 2011, 32:183-200.

17. De Zegher FI, Boehmer ALM, Saggese G, Müller J, Hiort O, Sultan C, Clayton P, Brauner R, Cacciari E, lbanez L, van Vliet G, Tiulpakov A, Saka N, Ritzen M, Sippell WG: Androgens and fetal growth. Horm Res 1998, 50:243-244.

18. Jurgensen M, Hiort $\mathrm{O}$, Holterhus PM, Thyen U: Gender role behavior in children with XY karyotype and disorders of sex development. Horm Behav 2007, 51:443-453.

19. Han TS, Goswami D, Trikudanathan S, Creighton SM, Conway GS: Comparison of bone mineral density and body proportions between women with complete androgen insensitivity syndrome and women with gonadal dysgenesis. Eur J Endocrinol 2008, 159:179-185.

20. Maimoun L, Philibert P, Cammas B, Audran F, Bouchard P, Fenichel P, Cartigny M, Pienkowski C, Polak M, Skordis N, Mazen I, Ocal G, Berberoglu M, Reynaud R, Baumann C, Cabrol S, Simon D, Kayemba-Kay's K, De Kerdanet M, Kurtz F, Leheup B, Heinrichs C, Tenoutasse S, Van Vliet G, Grüters A, Eunice M, Ammini AC, Hafez M, Hochberg Z, Einaudi S, et al: Phenotypical, biological, and molecular heterogeneity of 5 a-reductase deficiency: an extensive international experience of 55 patients. J Clin Endocrinol Metab 2011, 96:296-307.

21. Ngun TC, Ghahramani N, Sánchez FJ, Bocklandt S, Vilain E: The genetics of sex differences in brain and behavior. Front Neuroendocrinol 2011, 32:227-246.

22. Hochberg Z: Evo-devo of child growth II: human life history and transition between its phases. Eur J Endocrinol 2009, 160:135-141.

23. Hiort O: Androgens and puberty. Best Pract Res Clin Endocrinol Metab 2002, 16:31-41.

24. Deslypere JP, Young M, Wilson JD, McPhaul MJ: Testosterone and 5 alphadihydrotestosterone interact differently with the androgen receptor to enhance transcription of the MMTV-CAT reporter gene. Mol Cell Endocrinol 1992, 88:15-22.

25. Holterhus PM, Piefke S, Hiort O: Anabolic steroids, testosterone-precursors and virilizing androgens induce distinct activation profiles of androgen responsive promoter constructs. J Steroid Biochem Molec Biol 2002, 82:269-275

26. Hellwinkel OJC, Müller A, Struve D, Hiort O: Influence of androgens and age on androgen receptor and 5a-reductase II transcription. Eur J Endocrinol 2000, 143:217-225.

27. Hellwinkel OJC, Bassler J, Hiort O: Transkription of androgen receptor and 5a-reductase II in genital skin fibroblasts from patients with androgen insensitivity syndrome. J Steroid Biochem Molec Biol 2000, 75:213-218.

28. Thiele S, Hoppe U, Holterhus PM, Hiort O: Isoenzyme type 1 of $5 a-$ reductase is abundantly transcribed in normal human genital skin fibroblasts and may play an important role in masculinization of 5a-reductase type 2 deficient males. Eur J Endocrinol 2005, 152:875-880.

29. Hoppe U, Holterhus PM, Wünsch L, Jocham D, Drechsler T, Thiele S, Marschke C, Hiort O: Tissue-specific transcription profiles of sex steroid biosynthesis enzymes and the androgen receptor. J Mol Med 2006, 84:651-659.

30. Hoppe U, Wünsch L, Holterhus PM, Jocham D, Richter-Unruh A, Hiort O: Altered transcription profiles of key-enzymes of androgen biosynthesis in genital skin fibroblasts from patients with $46, \mathrm{XY}$ disorders of sex development. Sex Dev 2007, 1:230-237.

31. Werner R, Kulle A, Sommerfeld I, Riepe FG, Wudy S, Hartmann MF, Merz H, Döhnert U, Bertelloni S, Holterhus PM, Hiort O: Testosterone synthesis in patients with 17ß-hydroxysteroid dehydrogenase 3 deficiency. Sex Dev 2012, 6:161-168

32. Jenster G, Trapman J, Brinkmann AO: Nuclear import of the human androgen receptor. Biochem J 1993, 293:761-768.

33. Shaffer PL, Jivan A, Dollins DE, Claessens F, Gewirth DT: Structural basis of androgen receptor binding to selective androgen response elements. Proc Natl Acad Sci U S 2004, 101:4758-4763.

34. Lonard DM, Lanz RB, O'Malley BW: Nuclear receptor coregulators and human disease. Endocr Rev 2007, 28:575-587.

35. Lonard DM, O'Malley BW: Nuclear receptor coregulators: judges, juries, and executioners of cellular regulation. Mol Cell 2007, 27:691-700.

36. Bebermeier JH, Brooks J, DePrimo S, Werner R, Deppe U, Demeter J, Hiort O, Holterhus PM: Cell-line and tissue specific signatures of androgen receptor coregulator transcription. J Mol Med 2006, 84:919-931.

37. Holterhus PM, Hiort O, Demeter J, Brown PO, Brooks JD: Differential gene expression patterns in genital fibroblasts of normal and $46, X Y$-females with androgen insensitivity syndrome: evidence for early programming involving the androgen receptor. Genome Biol 2003, 4:R37.

38. Holterhus PM, Deppe U, Werner R, Richter-Unruh A, Bebermeier JH, Wunsch L, Krege S, Schweikert HU, Demeter J, Riepe F, Hiort O, Brooks JD: Intrinsic androgen-dependent gene expression patterns revealed by comparison of genital fibroblasts from normal males and individuals with complete and partial androgen insensitivity syndrome. BMC Genomics 2007, 18:376

39. Appari M, Werner R, Wünsch L, Cario G, Demeter J, Hiort O, Riepe F, Brooks JD, Holterhus PM: Apolipoprotein D (APOD) is a putative biomarker of androgen receptor function in androgen insensitivity syndrome. $J \mathrm{Mo}$ Med 2009, 87:623-632 
40. Holterhus PM, Bebermeier JH, Werner R, Demeter J, Richter-Unruh A, Cario G, Appari M, Siebert R, Riepe F, Brooks JD, Hiort O: Disorders of sex development expose transcriptional autonomy of genetic sex and androgen-programmed hormonal sex in human blood leukocytes. BMC Genomics 2009, 10:292.

41. Bens S, Ammerpohl O, Martin-Subero Jl, Appari M, Richter J, Hiort O, Werner R, Riepe FG, Siebert R, Holterhus PM: Androgen receptor mutations are associated with altered epigenomic programming as evidenced by HOXA5 methylation. Sex Dev 2011, 5:70-76.

doi:10.1186/1741-7015-11-152

Cite this article as: Hiort: The differential role of androgens in early

human sex development. BMC Medicine 2013 11:152.

\section{Submit your next manuscript to BioMed Central and take full advantage of:}

- Convenient online submission

- Thorough peer review

- No space constraints or color figure charges

- Immediate publication on acceptance

- Inclusion in PubMed, CAS, Scopus and Google Scholar

- Research which is freely available for redistribution 